Article

\title{
An Introduction to a Novel and Rapid nZEB Skill-Mapping and Qualification Framework Methodology
}

\author{
Jan Cromwijk $^{1, *}$, Carolina Mateo-Cecilia ${ }^{2}$, Cristina Jareño-Escudero ${ }^{2}$ (D), Veronika Schröpfer ${ }^{3}$ \\ and Peter Op't Veld ${ }^{4}$ \\ 1 Stichting ISSO, 3013 AL Rotterdam, The Netherlands \\ 2 Valencia Institute of Building, 46018 Valencia, Spain; cmateo@five.es (C.M.-C.); cjareno@five.es (C.J.-E.) \\ 3 Architects' Council of Europe, 1050 Brussels, Belgium; veronika.schropfer@ace-cae.eu \\ 4 Huygen Installatie Adviseurs B.V., 6200 AM Maastricht, The Netherlands; p.optveld@huygen.net \\ * Correspondence: j.cromwijk@isso.nl
}

Received: 22 September 2017; Accepted: 7 November 2017; Published: 19 November 2017

\begin{abstract}
Successful design and construction processes aiming towards nearly zero energy building (nZEB) standards are a challenge for the whole construction industry in Europe. Realizing nZEB buildings requires innovative design processes, and technologies based on an integrated design approach facilitated by multidisciplinary work teams. The collaboration between architects, engineers, technical experts and building managers, is essential. Therefore, it is necessary to identify the specific involvement of each profession in order to develop mutual understanding of each others' disciplines. Additionally, it is vital to provide professionals with the skills needed to achieve optimal nZEB construction and retrofitting in terms of quality, energy efficiency and cost effectiveness. However, this approach is not yet common, as the building sector is still very fragmented. The EU-funded H2020 project PROF/TRAC aims to tackle this issue by developing an Open Training Platform and a methodology for fast and valid co-creation of interdisciplinary qualification schemes for task-based Continuous Professional Development (CPD) for all professions involved. A common methodology for the mapping of skills and qualifications in the form of an Excel tool was developed as a basis, together with a guidance document. This paper presents the skill-mapping methodology, the use of its results to develop national roadmaps, and the BUILD UP Skills advisor app.
\end{abstract}

Keywords: Nearly Zero Energy Building (nZEB); sustainable construction; construction skills; skills gap; skills mapping methodology; multidisciplinary; certification structures; Continuing Professional Development; EU funding; BUILD UP Skills advisor app

\section{Introduction}

Cities consume three quarters of the world's natural resources. Globally, buildings account for about $40 \%$ of energy use, approximately $25 \%$ of global water use and circa $30 \%$ of greenhouse gas emissions [1]. The residential building stock was responsible for about one quarter of total energy consumption in 2014. This consumption, together with non-residential buildings' consumption, reached about $38 \%$ of the final energy consumption, representing the largest energy-consuming sector in Europe [2]. In addition to the resource aspects, buildings have a major impact on social and health aspects. On average, humans living in urban settings spend up to $90 \%$ of each day inside buildings [3]. Hence, the quality of the built environment influences their health, comfort, security, and ways of cooperating with each other. For this reason, European energy and climate policies have ambitious climate goals, which are reflected in the Low-Carbon Europe Roadmap 2050. The European Commission has emphasized the importance of achieving these objectives with its recasting of the 
Energy Performance of Buildings Directive (EPBD), stating that new buildings built from 2021 onwards will have to be nZEB.

However, while acknowledging the relevance of nZEB, there has not yet been an empirical demonstration of an optimal design approach. The nature of projects where the ultimate goal is to deliver a nZEB is more complex than that of standard projects [4]. This is due to the increased number of people involved, in addition to the modified technical knowledge [5]. Furthermore, the supply chains of new sustainable building materials are more distributed than for conventional ones. Sustainable buildings require high-tech components, which are supplied by specialized companies, e.g., building control technologies or use of solar energy. Thus, various sorts of new services and consultancies become important, as a high level of expertise is required to solve the complex problems of building sustainably [6].

In addition, various studies and reports have revealed an actual lack of knowledge and understanding the sustainability concept among practitioners in the field [5-10]. Lack of knowledge, trust, and communication between various stakeholders of the lifecycle stages of a building have also been identified as a main barrier $[5,11]$. This leads to the question as to whether this lack of specialized knowledge is one of the reasons for the underperformance of sustainable buildings [5].

The codes, standards and procedures have created lively debates and increased awareness within the building industry globally regarding the actions required to tackle climate change [12]. In this context, the design process needs to be a collaborative effort between all stakeholders. There is a substantial need for professionals, such as architects and engineers, to be specifically educated in an integrated design approach and trained to work in cross-disciplinary teams [13]. Previous efforts in integrated design have been undertaken in order to push development forward, for instance by the EU-funded project IDES-EDU. However, it is vital to include specific skills to cope with nZEB challenges in cross-disciplinary teams, which has not been sufficiently addressed by previous research. Moreover it is essential that educational institutions foster professionals with such knowledge, skills and competences.

Thus, energy performance optimization of buildings requires an integrated design approach and cross-disciplinary teamwork to optimize the building's energy use and the quality of indoor environments, while satisfying the occupants' needs [3]. Traditional engineering courses are regularly updated to cover emerging engineering technologies with regard to, for instance, solar and wind energy modules, which are added to mechanical and electrical engineering courses, instead of holistic approaches [12]. According to Yang, Ergan and Knox [14], an advanced nZEB design requires effective and efficient sharing of information among members from different disciplines in an Integrated Design Group (IDG) in order to make wise decisions about selecting the right set of energy retrofit design options. This could be achieved by introducing Integrated Product Design (IPD) into the nZEB design process. This method is able to cope with the technical, as well as aesthetic, issues that need to be solved in an integrated building design. It focuses on the creative element in the process, in order to identify new opportunities and produce innovative solutions in a new building design. Therefore, the architect's ability to see new possibilities and to work strategically and interdisciplinary by designing an architecture that engages with engineering parameters is crucial [15]. IPD is highly collaborative and iterative in nature, and can involve the participation of various disciplines in addition to architects, such as engineers, contractors and project managers, from the inception of a project $[13,15]$.

To enforce this integrated design approach, the EU funded Horizon 2020 project PROF/TRAC was set-up to define the main concepts and develop cross-disciplinary expertise in integrated energy-efficient building design for nZEB, following previous projects, such as IDES-EDU [13]. This paper presents part of its results; specifically, a Qualification Framework and methodology for fast and valid co-creation of interdisciplinary qualification schemes for task-based CPD for all nZEB professionals involved. This methodology can be applied to new nZEB constructions, as well as to retrofitting, within both the residential and non-residential sectors. This paper describes the results of newly developed cross-disciplinary methodologies established by seven different 
educational institutions in Europe. Finally, it explains and discusses the challenges encountered during development and implementation across different professions and countries, and concludes with further research recommendations.

The PROF/TRAC approach to tackle the issue of up-skilling the professions involved is threefold. First, the lack of knowledge described above is quantified by mapping the required skills and current skill gaps of professionals with regard to nZEB-related technologies and interdisciplinary skills. Second, the challenge of producing the right information on available qualifications and training materials is addressed. PROF/TRAC developed a repository of training material for free use in education and post-initial education in the Open Training Platform on its project website. This is mainly based on the results of the IDES-EDU project [13]. Furthermore, PROF/TRAC pilots, how the BUILD UP Skills advisor app (H2020 projects BUS_N@W and BUStoB) can be used to transfer CPD information and short 'update trainings' to nZEB professionals in the Netherlands. Thirdly, PROF/TRAC develops a task-based European qualification scheme as part of a lifelong learning process for continuous development and up-skilling of professionals. This qualification scheme will also be used to implement the narrowcasting in the BUILD UP Skills advisor app (ISSO, Rotterdam, The Netherlands). The expected users will mainly be training institutions, which will use the developed tools in order to prepare new training materials in the field of nZEB. Another group of users foreseen includes branch/trade organizations that represent several of the professions involved.

\section{Methodology}

\subsection{Introduction to the Common Methodology for the Mapping of Skills}

The first task has been the design of a common methodology for the mapping of skills, which consists of:

1. A mapping and comparison of the required nZEB skills versus present nZEB skills of professions involved in nZEB construction and retrofitting. This should provide an indication of the current skills gaps and mismatches;

2. An inventory of professions and interdisciplinary skills involved, technologies applied, existing qualifications, knowledge sources, education programs, post-initial training supply and accreditation/ certification structures;

3. Visualization of all technologies, interdisciplinary skills and involved professions. Figure 1 gives an overview of some of the visualisations.

Since the definition of skill levels is vital, they have been described in detail in the guidelines, together with the definitions used for involved professions in order to make the results better comparable. An important accelerator was the use of the right EU terms, in accordance with the Bologna declaration of 2010, as a foundation. Table 1 lists the various skill levels applied.

Table 1. Definition of the skill levels used in PROF/TRAC.

\begin{tabular}{cl}
\hline Skill-Level & Not Applicable/No Knowledge and Skills Required \\
\hline $\mathbf{1}$ & Has little knowledge and skills with respect to the relevant field/technology \\
\hline $\mathbf{2}$ & $\begin{array}{l}\text { Understands basic knowledge and has practical skills within the field, is able to solve problems by } \\
\text { selecting and applying basic methods, tools, materials and information }\end{array}$ \\
\hline $\mathbf{3}$ & Has comprehensive, factual and theoretical knowledge, is capable of solving problems within the field \\
\hline 4 & $\begin{array}{l}\text { Has advanced knowledge involving a critical understanding of theories and principles and skills, } \\
\text { required to solve complex and unpredictable problems in the field and is aware of the boundaries }\end{array}$ \\
\hline 5 & $\begin{array}{l}\text { Has specialized knowledge and problem-solving skills, partly at the forefront of knowledge in the field, } \\
\text { in order to develop new knowledge and procedures and to integrate knowledge from different fields }\end{array}$ \\
\hline \hline
\end{tabular}


The main idea of the skills mapping methodology was to support EU Member States in executing the skills mapping in a fast and practical way. The following actions were foreseen in the methodology for each country:

1. Creating an inventory of involved professions, number of professionals and their education levels (Table 2 gives an excerpt of involved professions);

2. Creating an inventory of existing qualifications;

3. Creating an inventory of available education programs;

4. Creating an inventory of post-initial trainings (CPD);

5. Creating an inventory of accreditation and certification structures;

6. Creating an inventory of applied nZEB building and installation technologies;

7. Creating an overview of required interdisciplinary skills;

8. Mapping the applied building and installation technologies with the involved professions and their EQF levels by national experts;

9. Mapping the required interdisciplinary skills with the involved professions and their EQF levels (European Qualification Framework) by national experts.

Table 2. Excerpt of the inventory of involved professions defined in PROF/TRAC.

\begin{tabular}{|c|c|c|}
\hline Profession & Definition of the Professions (Proposal) & EQF \\
\hline Architect & $\begin{array}{l}\text { The designer of buildings for human occupancy or use, who: } \\
\text { (a) visualizes the design and; } \\
\text { (b) supervises the building construction process }\end{array}$ & $5-8$ \\
\hline Engineer & $\begin{array}{l}\text { The designer of materials, structures and systems, } \\
\text { considering the limitations imposed by practicality, } \\
\text { regulation, safety and cost }\end{array}$ & $5-8$ \\
\hline Mechanical Engineer & Engineer of HVAC and plumbing installations & $5-8$ \\
\hline Electrical Engineer & $\begin{array}{l}\text { Engineer of electrical and lighting installations, } \\
\text { communication systems }\end{array}$ & $5-8$ \\
\hline Construction Engineer & $\begin{array}{l}\text { Engineer, who deals with statics, mechanics, solid mechanics } \\
\text { and with the conception, analysis, design and construction of } \\
\text { components or assemblies to resist loads arising from } \\
\text { internal and external forces. }\end{array}$ & $5-8$ \\
\hline Building Engineer & $\begin{array}{l}\text { Engineer of the building: design, drawings, materialization, } \\
\text { details, acoustics }\end{array}$ & $5-8$ \\
\hline Project manager & $\begin{array}{l}\text { The person responsible for the planning, execution and } \\
\text { closing of any (nZEB) building project }\end{array}$ & $5-8$ \\
\hline Project developer & $\begin{array}{l}\text { The project developer takes responsibility for the associated } \\
\text { risks involved in the building process for the customer and } \\
\text { hands over the project to the tenant/buyer after completion } \\
\text { and use of the building }\end{array}$ & $5-8$ \\
\hline Manager building process & $\begin{array}{l}\text { The person responsible for quality assurance during on-site } \\
\text { construction works in the realization of nZEB buildings }\end{array}$ & $5-8$ \\
\hline Building owner/Facility Manager & $\begin{array}{l}\text { The person responsible to maintain the property as it was } \\
\text { built (including facility management) }\end{array}$ & $1-8$ \\
\hline Financial manager & $\begin{array}{l}\text { The person responsible for all finances involved during } \\
\text { planning, execution and closing of any (nZEB) building } \\
\text { project }\end{array}$ & $5-8$ \\
\hline Procurer & $\begin{array}{l}\text { The person responsible for facilitating the process of nZEB } \\
\text { tenders and (sub-) contracts }\end{array}$ & $5-8$ \\
\hline
\end{tabular}

It is important to remark that actions eight and nine describe the gaps between the present and required skills in nZEB. The national roadmaps (see Section 2.3) used these results as starting point. 


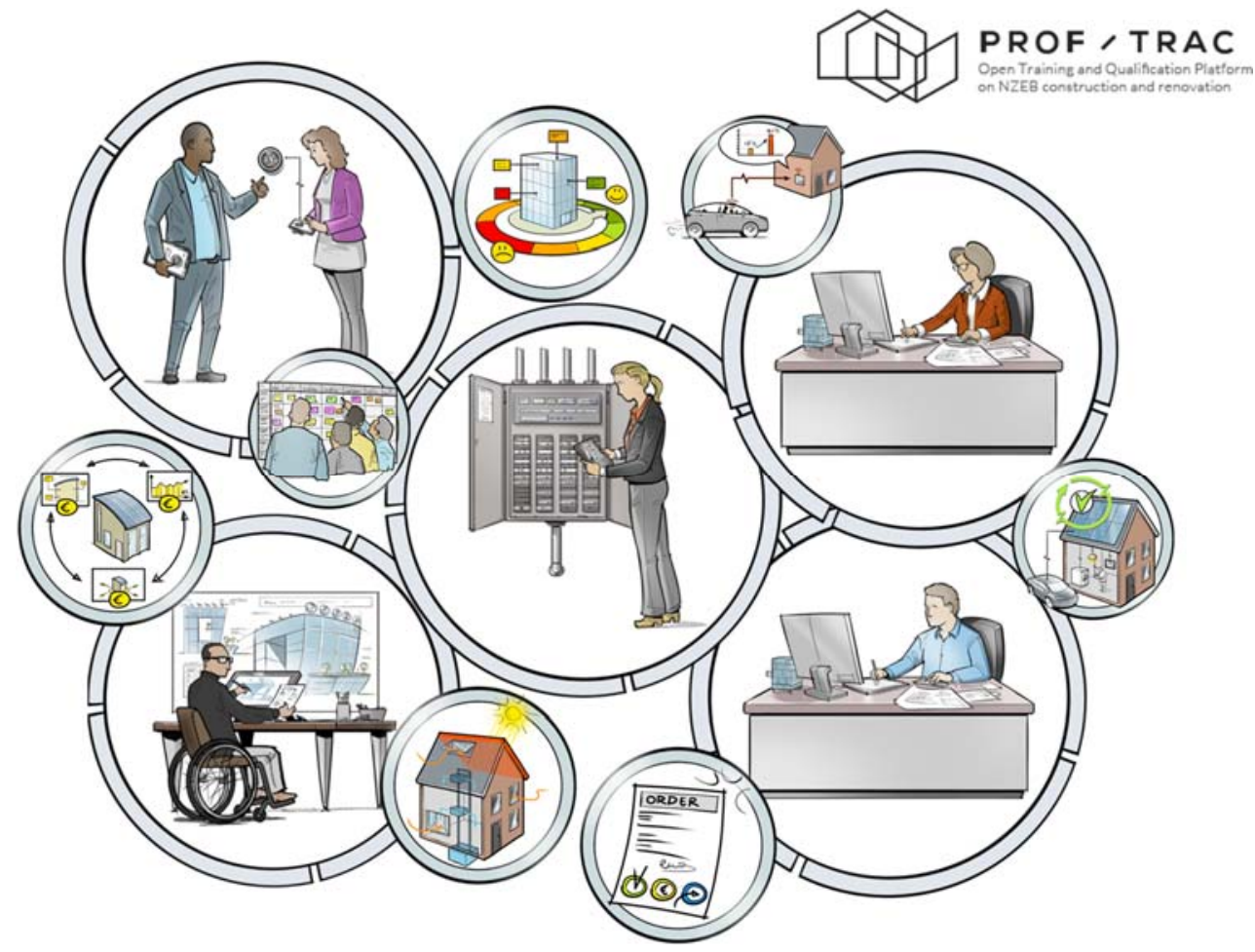

Figure 1. Visualizations of professions and technologies involved developed for the BUILD UP Skills Advisor App.

\subsection{Execution with Small Groups of Experts}

The second step was selecting professionals in seven member states to form small focus groups of four to six experts. The required professionals were defined as architect, engineer, building manager, and project developer. The experts selected had actual, high-level experience in realizing and maintaining nZEB buildings (new and renovated). The criteria that helped to select each of the experts were:

1. To have proven experience with nZEB (as architect, engineer, project manager, building company or installation company, project developer, teacher/trainer, building manager or scientist);

2. To know the national market of nZEB;

3. To have an interdisciplinary overview of actors involved in the nZEB construction and maintenance value chain;

4. To be able to not only use one approach on nZEB, but to recognize the value of other approaches (Passiv Haus, Active House, Zero Energy Bill, etc.);

5. To know available relevant education and/or post-initial trainings;

6. To be able to answer the skills mapping methodology questions or be able to find people who could provide answers (relevant expertise or network);

7. To support EU projects like PROF/TRAC and be personally motivated and committed to use the results;

8. To have good communication skills, knowledge of language and ICT.

These national experts were trained in the skill-mapping methodology in a short 30 min training during the first PROF/TRAC train the trainer event. As a result, raw first versions of the national results were presented at this event, compared and discussed between the experts present. Finally, the trained expert groups executed the skill mapping in their own countries. 
As a validation, the results of the skill mappings delivered by the expert groups were then validated through the project consortium, e.g., regarding the skills of architects, the Architects' Council of Europe had a CPD expert reviewing them for all undertaken countries. This action was the outset for developing a generic nZEB qualification scheme for the involved professions (see Section 2.4).

\subsection{Roadmap Development}

This was followed by the development of national roadmaps. In this task, each pilot country developed a roadmap on how to address and close the uncovered skill gaps. Each of the developed roadmaps focused on the successful national implementation of nZEB trainings for professionals, linked to the upcoming PROF/TRAC EU nZEB qualification scheme. The aim of each document was to identify measures to overcome barriers and skills gaps for a successful national implementation of nZEB training for professionals. The roadmap format was elaborated at a detailed level, so that it could easily be used as a writing guide. During the writing phase, several best-practice examples for improving the format were discussed in the consortium, resulting in an improved roadmap template, which is outlined in Figure 2.

\section{TABLE OF CONTENT}

Change records

Roadmap Summary

List of abbreviations and definitions

1 Introduction

1.1 Guidance of this report

2 Demands for skilled professionals - results skills mapping

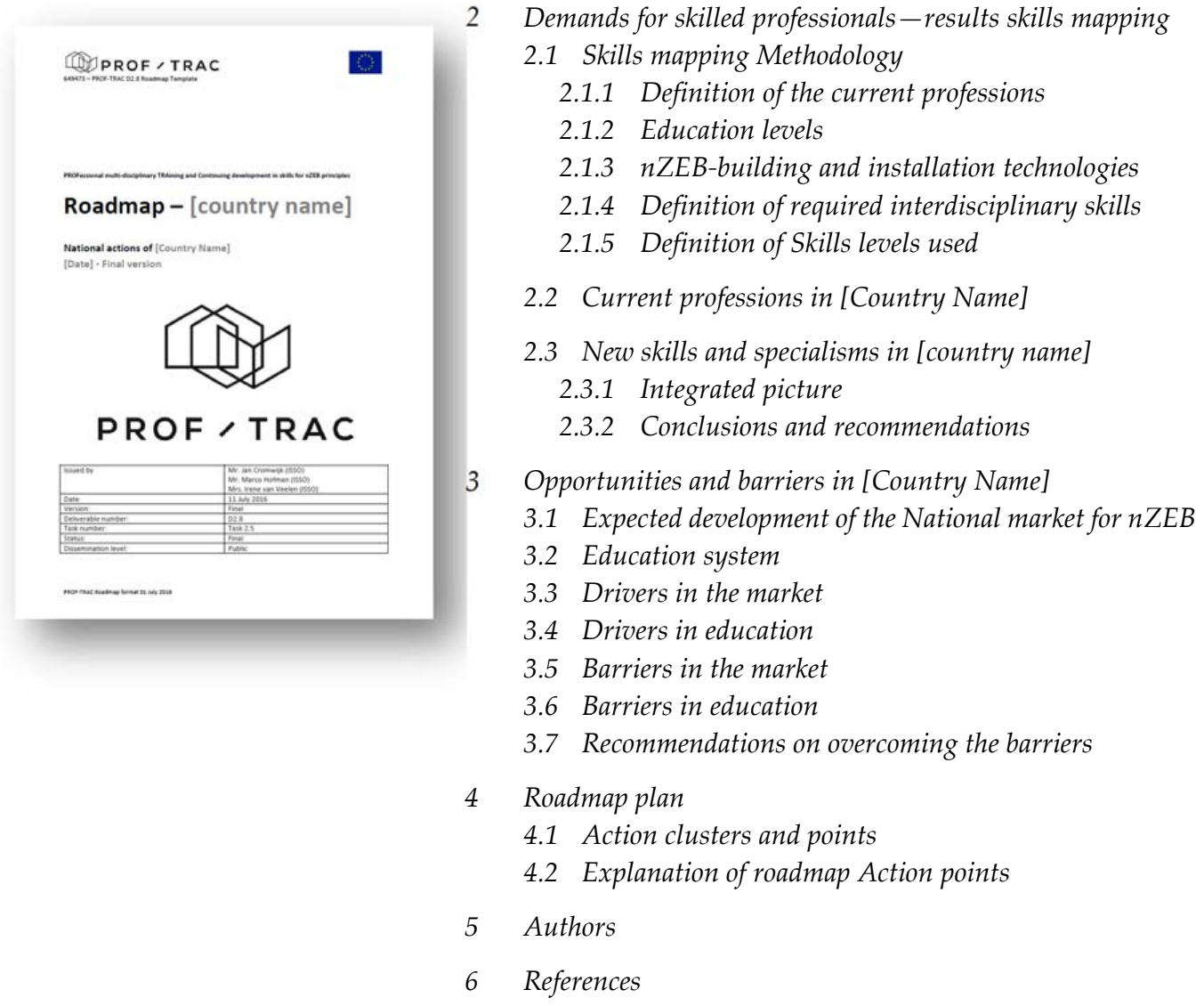

Figure 2. Roadmap template and table of content developed in PROF/TRAC. 
The first part of the document provides a brief summary of requirements for skilled professionals, as a result of national skill mapping. This part of the report is focused on the national definition of professions involved in nZEB construction and retrofitting, as well as the description of their present and required skills. Additionally, it includes a short description of the skill mapping methodology, in order to show the demand for skilled professionals on the market, as well as the overview of the most noteworthy conclusions for each profession.

The second part of the document deals with the opportunities and barriers to the objective of the PROF/TRAC project, and covers areas such as:

- Expected development of the national market for nZEB;

- Drivers and barriers to the market;

- Education system;

- Drivers and barriers in education;

- Recommendations on overcoming the barriers.

Finally, the third part of the document presents the roadmap plan for this specific country, including proposed national actions. By identifying specific actions, it is believed that the roadmap could become a tool for implementing change in the building sector, but in particular for the implementation of changes to the qualifications and skills of building professionals in each country based on the skill mapping methodology. Implementation of the roadmap will allow ensuring that relevant professionals in the building sector have the necessary knowledge and skills for the design, construction and operation of nZEB buildings.

\subsection{Development of the PROF/TRAC nZEB Qualification Framework}

The development of the PROF/TRAC nZEB Qualification Framework is further elaborated here, while the actual content of the framework is currently being finalized, and will be available on the project website from December 2017 onwards. It consists of several components:

1. Four different macro areas of expertise: Energy management, Energy production, Energy reduction and Interdisciplinary skills;

2. General or non-task-specific knowledge and skills;

3. Subtasks related to project phases and work fields;

4. The required skill levels (results from the skills mapping).

Table 3 depicts the qualification framework for the example of the heat pump technology.

The PROF/TRAC nZEB Qualification Framework is used in the BUILD UP Skills advisor app to narrowcast training content related to involved professions, technologies and interdisciplinary skills. When the nZEB Qualification Framework is finalized, it will be first used in the Netherlands in Dutch and on an EU level in English, in order to provide fast and effective insights into available CPD supply. The described professional tasks will be used as a filter, to further narrow down the relevant CPD supply. Here the professionals will be able to find technology, interdisciplinary and task-specific training content within four navigation steps. Figure 3 depicts the app. The first screen is the splash-screen. On the second screen you can select your profession. Based on the profession you selected, the CPD-training supply is filtered for the best fit. 
Table 3. PROF/TRAC Qualification Framework for the heat pump technology.

\begin{tabular}{|c|c|c|c|c|c|c|c|c|}
\hline \multicolumn{9}{|c|}{ Technology Nr. } \\
\hline EP5 & Planning and design of heat pump installations & \multicolumn{7}{|c|}{$\begin{array}{l}\text { energy production for heating, cooling and potable hot } \\
\text { water, making use of an energy source with low } \\
\text { temperature and bringing it to a higher temperature. }\end{array}$} \\
\hline \multirow[t]{2}{*}{ Project phase } & General description and subtasks & \multicolumn{7}{|c|}{ Workfield } \\
\hline & & 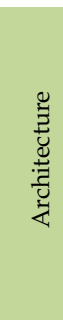 & 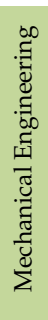 & 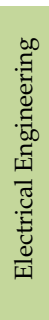 & 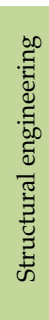 & 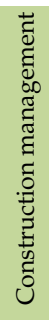 & 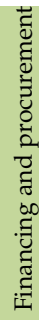 & 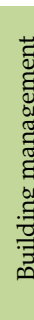 \\
\hline \multirow[t]{3}{*}{ General } & $\begin{array}{l}\text { General knowledge of heat pumps, design and } \\
\text { application }\end{array}$ & 1 & 4 & 2 & 1 & 1 & 1 & 1 \\
\hline & $\begin{array}{l}\text { Understands the basic working and application of heat } \\
\text { pumps, is able to explain and discuss. }\end{array}$ & $\mathrm{x}$ & $\mathrm{x}$ & $\mathrm{x}$ & $\mathrm{x}$ & $\mathrm{x}$ & $\mathrm{x}$ & $\mathrm{x}$ \\
\hline & $\begin{array}{l}\text { Is aware of types of available heat sources for use with } \\
\text { heat pumps, understands the influence of source } \\
\text { temperature on energy efficiency. }\end{array}$ & & $\mathrm{x}$ & $\mathrm{x}$ & & & & \\
\hline Pre design & Performance of a feasibility study & 2 & 5 & 3 & 1 & 1 & 1 & - \\
\hline Design & Detailed engineering of the heat pump system & 2 & 5 & 3 & 1 & 1 & 1 & - \\
\hline Contracting & Specification of heat pumps for contracting purpose & - & 4 & 2 & - & - & 2 & - \\
\hline Realisation & $\begin{array}{l}\text { Can manage, instructs and audit contractors during } \\
\text { realisation of a heat pump system }\end{array}$ & 2 & 4 & 2 & - & 2 & - & - \\
\hline Commissioning & $\begin{array}{l}\text { Can commission a heat pump system under all } \\
\text { conditions (full, partial load, seasonal performance) }\end{array}$ & 2 & 4 & 2 & - & - & - & 2 \\
\hline Use & Setting up a maintenance plan and user instruction & - & 4 & - & - & - & - & 2 \\
\hline
\end{tabular}

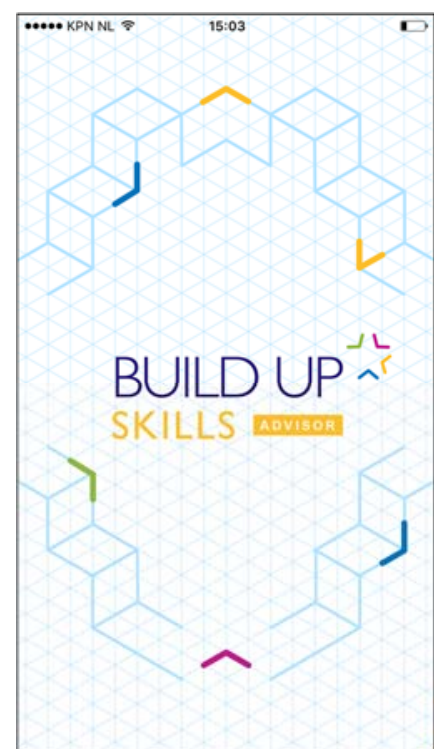

(a)

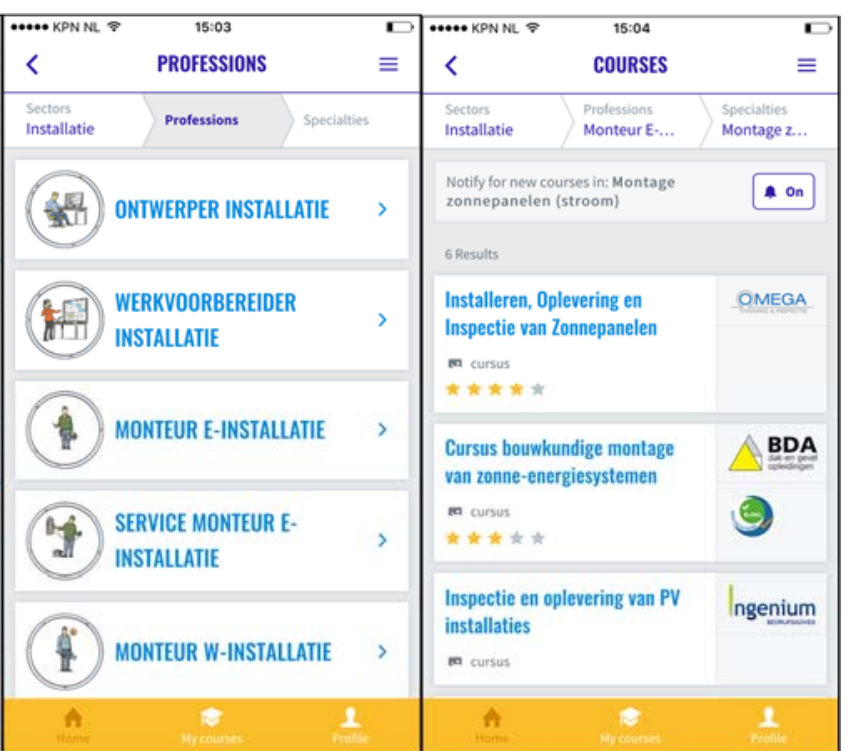

(b)

(c)

Figure 3. Integration with the BUILD UP Skills advisor app with Dutch content (English content expected at the end of 2017) (a) splash screen; (b) selection of profession; (c) CPD-training supply for the selected profession 


\section{Results}

One of PROF/TRAC's main outputs is the mapping of the professions concerned in nZEB construction and retrofitting including a mapping of the required specific skills versus the present available skills. This includes the mapping of the technologies involved, interdisciplinary skills, existing qualifications, knowledge sources, education programs, post-initial training supply and accreditation and certification structures. While skills related to technology focus on nZEB related issues are grouped in different energy related items, according to the Trias Energetica concept (energy reduction, production and efficiency/management), interdisciplinary skills focus on the direct relations and interaction points between the different disciplines in the building sector [16].

The first step in PROF/TRAC was the mapping of existing skills and qualifications in the EU. Starting from the real skills situation in each country and comparing these with the required skills for developing and maintaining nZEBs. PROF/TRAC developed a common methodology for the mapping of skills and qualifications by categorizing technologies, interdisciplinary skills and professions involved. Seven PROF/TRAC pilot countries mapped the current and required skills of professionals on nZEB technologies and skills, together with the existing qualifications in their country. The gaps between current and required skills identify the need for additional training in order to obtain skills and knowledge necessary to successfully construct or refurbish nZEB buildings. Tables 4 and 5 contain a part of the skills mapping results from the Netherlands and Spain, the higher the level (from 1-5) the larger the gap between current and expected nZEB knowledge and skills.

Table 4. PROF/TRAC skills mapping result for the Netherlands, 2016.

\begin{tabular}{|c|c|c|c|c|c|c|c|c|c|c|c|c|c|c|c|c|c|c|c|c|c|c|c|c|c|}
\hline \multirow{2}{*}{ Оิ } & \multirow{2}{*}{$\begin{array}{c}\text { Technology, } \\
\text { Interdiscipli-Nary } \\
\text { Skills and } \\
\text { Professions }\end{array}$} & \multicolumn{8}{|c|}{ Architect } & \multicolumn{8}{|c|}{ Building Engineer } & \multicolumn{8}{|c|}{ Construction Engineer } \\
\hline & & 营 & 疍 & छి & - & $N$ & $m$ & $H$ & in & $\begin{array}{l}\vec{\Xi} \\
\stackrel{\Xi}{\Xi}\end{array}$ & 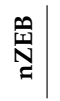 & ज़ & $r$ & $N$ & $m$ & + & in & 节 & 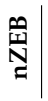 & ज़ & $r$ & $N$ & $m$ & 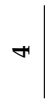 & in \\
\hline $\mathbf{M}$ & \multicolumn{25}{|c|}{ Energy Management } \\
\hline EM1 & Smart grid systems & $1 \mid$ & $\mid 1$ & 0 & & & & & & 1 & $1 \mid$ & 0 & & & & & & 0 & 0 & 0 & & & & & \\
\hline EM2 & Domotic systems & 11 & 3 & 2 & & & & & & 1 & $1 \mid$ & 0 & & & & & & 0 & 0 & 0 & & & & & \\
\hline EM3 & $\begin{array}{l}\text { Building } \\
\text { management } \\
\text { systems }\end{array}$ & 1 & 2 & 1 & & & & & & 1 & 1 & 0 & & & & & & 0 & 0 & 0 & & & & & \\
\hline $\mathbf{P}$ & \multicolumn{25}{|c|}{ Energy Production } \\
\hline EP1 & Geothermal energy & 0 & 1 & 1 & & & & & & 0 & 01 & 0 & & & & & & 0 & 0 & 0 & & & & & \\
\hline EP2 & Biomass & 0 & 1 & 1 & & & & & & 0 & 0 & 0 & & & & & & 0 & 0 & 0 & & & & & \\
\hline EP3 & Biogass & 0 & 1 & 1 & & & & & & 0 & $0 \mid$ & 0 & & & & & & 0 & 0 & 0 & & & & & \\
\hline EP4 & $\begin{array}{l}\text { Districtheating and } \\
\text { cooling }\end{array}$ & 1 & 2 & 1 & & & & & & 1 & 0 & 0 & & & & & & 0 & 0 & 0 & & & & & \\
\hline EP5 & Heatpumps & 1 & 2 & 1 & & & & & & 1 & $1 \mid$ & 0 & & & & & & 1 & 1 & 0 & & & & & \\
\hline EP6 & $\begin{array}{l}\text { Solar power } \\
\text { systems for } \\
\text { electricity } \\
\text { generation }\end{array}$ & 2 & 3 & 1 & & & & & & 2 & 2 & 0 & & & & & & 1 & 1 & 0 & & & & & \\
\hline EP7 & $\begin{array}{l}\text { Solar thermal } \\
\text { systems for cooling } \\
\text { generation }\end{array}$ & 1 & 1 & 0 & & & & & & 1 & 1 & 0 & & & & & & 1 & 1 & 0 & & & & & \\
\hline EP8 & $\begin{array}{l}\text { Solar thermal } \\
\text { systems for } \\
\text { domestic hot water } \\
\text { and/or heating } \\
\text { generation) }\end{array}$ & 2 & 1 & 0 & & & & & & 1 & 1 & 0 & & & & & & 1 & 1 & 0 & & & & & \\
\hline EP9 & Mini wind power & 01 & 1 & 1 & & & & & & 0 & $1 \mid$ & 1 & & & & & & 0 & 2 & 2 & & & & & \\
\hline EP10 & $\begin{array}{l}\text { Combined Heat } \\
\text { and Power (CHP) }\end{array}$ & 0 & 1 & 1 & & & & & & 0 & 1 & 1 & & & & & & 0 & 1 & 1 & & & & & \\
\hline
\end{tabular}


Table 4. Cont.

\begin{tabular}{|c|c|c|c|c|c|c|c|c|c|c|c|c|c|c|c|c|c|c|c|c|c|c|c|c|c|}
\hline \multirow{2}{*}{ Оิ } & \multirow{2}{*}{$\begin{array}{c}\text { Technology, } \\
\text { Interdiscipli-Nary } \\
\text { Skills and } \\
\text { Professions }\end{array}$} & \multicolumn{8}{|c|}{ Architect } & \multicolumn{8}{|c|}{ Building Engineer } & \multicolumn{8}{|c|}{ Construction Engineer } \\
\hline & & 苞 & ํㅝㄹ & है & $r$ & $N$ & $m$ & 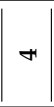 & n & 若 & 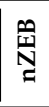 & ड़ & - & $N$ & $m$ & + & in & $\begin{array}{l}\vec{E} \\
\stackrel{\vec{D}}{E} \\
\mathrm{U}\end{array}$ & 品 & ज़ & - & $N$ & $m$ & 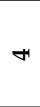 & in \\
\hline $\mathbf{R}$ & \multicolumn{25}{|c|}{ Energy Reduction } \\
\hline ER1 & Insulation & 3 & 4 & 1 & & & & & & 4 & 5 & 1 & & & & & & 3 & 2 & 0 & & & & & \\
\hline ER2 & $\begin{array}{l}\text { Air tightness } \\
\text { building }\end{array}$ & 3 & 4 & 1 & & & & & & 4 & 5 & 1 & & & & & & 2 & 2 & 0 & & & & & \\
\hline ER3 & Micro climates & 2 & 4 & 2 & & & & & & 3 & 2 & 0 & & & & & & 1 & 2 & 1 & & & & & \\
\hline ER4 & Envelope systems & 2 & 4 & 2 & & & & & & 3 & 3 & 0 & & & & & & 1 & 3 & 2 & & & & & \\
\hline ER5 & Hot water systems & 1 & 2 & 1 & & & & & & 1 & 1 & 0 & & & & & & 1 & 0 & 0 & & & & & \\
\hline ER6 & $\begin{array}{l}\text { Window and/or } \\
\text { glazing systems }\end{array}$ & 3 & 3 & 0 & & & & & & 4 & 4 & 0 & & & & & & 2 & 2 & 0 & & & & & \\
\hline ER7 & $\begin{array}{l}\text { Heating and } \\
\text { cooling emission } \\
\text { systems }\end{array}$ & 2 & 3 & 1 & & & & & & 2 & 2 & 0 & & & & & & 1 & 1 & 0 & & & & & \\
\hline ER8 & $\begin{array}{l}\text { Electric heating } \\
\text { systems }\end{array}$ & 1 & 1 & 0 & & & & & & 1 & 1 & 0 & & & & & & 1 & 1 & 0 & & & & & \\
\hline ER9 & $\begin{array}{l}\text { Artificial lighting } \\
\text { systems }\end{array}$ & 2 & 2 & 0 & & & & & & 2 & 2 & 0 & & & & & & 1 & 1 & 0 & & & & & \\
\hline ER10 & Ventilation systems & 2 & 2 & 0 & & & & & & 2 & 2 & 0 & & & & & & 1 & 1 & 0 & & & & & \\
\hline $\mathrm{S}$ & \multicolumn{25}{|c|}{ Interdisciplinary Skills } \\
\hline IS1 & Communication & 4 & 5 & 1 & & & & & & 3 & 3 & $0 \mid$ & & & & & & 3 & 3 & 0 & & & & & \\
\hline IS2 & $\begin{array}{l}\text { Information } \\
\text { management }\end{array}$ & 4 & 4 & 0 & & & & & & 4 & 3 & 0 & & & & & & 3 & 3 & 0 & & & & & \\
\hline IS3 & Collaboration & 3 & 4 & 1 & & & & & & 3 & 3 & 0 & & & & & & 2 & 3 & 1 & & & & & \\
\hline IS4 & Quality assurance & 3 & 4 & 1 & & & & & & 3 & 4 & 1 & & & & & & 4 & 4 & 0 & & & & & \\
\hline IS5 & $\begin{array}{c}\text { Sustainable } \\
\text { architectural design }\end{array}$ & 4 & 5 & 1 & & & & & & 3 & 3 & 0 & & & & & & 2 & 3 & 1 & & & & & \\
\hline IS6 & Integrated design & 3 & 4 & 1 & & & & & & 3 & 3 & 0 & & & & & & 3 & 3 & 0 & & & & & \\
\hline IS7 & $\begin{array}{c}\text { Sustainable } \\
\text { building materials }\end{array}$ & 3 & 4 & 1 & & & & & & 3 & 5 & 2 & & & & & & 2 & 2 & 0 & & & & & \\
\hline IS8 & $\begin{array}{c}\text { Sustainable } \\
\text { installation } \\
\text { materials }\end{array}$ & 2 & 2 & 0 & & & & & & 2 & 2 & 0 & & & & & & 1 & 1 & 0 & & & & & \\
\hline IS9 & $\begin{array}{l}\text { Environmental } \\
\text { (indoor) quality }\end{array}$ & 3 & 3 & 0 & & & & & & 2 & 2 & 0 & & & & & & 1 & 1 & 0 & & & & & \\
\hline IS10 & Economics & 3 & 3 & 0 & & & & & & 2 & 2 & 0 & & & & & & 2 & 3 & 1 & & & & & \\
\hline IS11 & Procurement & 2 & 3 & 1 & & & & & & 2 & 1 & 0 & & & & & & 2 & 1 & 0 & & & & & \\
\hline
\end{tabular}

Table 5. PROF/TRAC skills mapping result for Spain, 2016.

\begin{tabular}{|c|c|c|c|c|c|c|c|c|c|c|c|c|c|c|c|c|c|c|c|c|c|c|c|c|c|}
\hline \multirow{2}{*}{ Оิ } & \multirow{2}{*}{$\begin{array}{c}\text { Technology, } \\
\text { Interdiscipli-Nary } \\
\text { Skills and } \\
\text { Professions }\end{array}$} & \multicolumn{8}{|c|}{ Technical Architect } & \multicolumn{8}{|c|}{ Architect } & \multicolumn{8}{|c|}{ Technical Industrial Engineer } \\
\hline & & 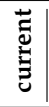 & 疍 & जี & -1 & $N$ & $m$ & H & in & 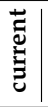 & 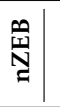 & जี & $\rightarrow$ & N & $m$ & + & in & 离 & 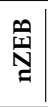 & है & -1 & $N$ & $n$ & r & in \\
\hline $\mathbf{M}$ & \multicolumn{25}{|c|}{ Energy Management } \\
\hline EM1 & Smart grid systems & 1 & 1 & 0 & & & & & & 2 & $2 \mid$ & 0 & & & & & & 2 & 2 & 0 & & & & & \\
\hline EM2 & Domotic systems & 2 & 2 & 0 & & & & & & 3 & 31 & 0 & & & & & & 3 & 2 & 0 & & & & & \\
\hline EM3 & $\begin{array}{c}\text { Building } \\
\text { management } \\
\text { systems }\end{array}$ & 1 & 2 & 1 & & & & & & 2 & 3 & 1 & & & & & & 2 & 2 & 0 & & & & & \\
\hline
\end{tabular}


Table 5. Cont.

\begin{tabular}{|c|c|c|c|c|c|c|c|c|c|c|c|c|c|c|c|c|c|c|c|c|c|c|c|c|c|}
\hline \multirow{2}{*}{ Oิ } & \multirow{2}{*}{$\begin{array}{c}\text { Technology, } \\
\text { Interdiscipli-Nary } \\
\text { Skills and } \\
\text { Professions }\end{array}$} & \multicolumn{8}{|c|}{ Technical Architect } & \multicolumn{8}{|c|}{ Architect } & \multicolumn{8}{|c|}{ Technical Industrial Engineer } \\
\hline & & $\begin{array}{l}\overrightarrow{\vec{E}} \\
\stackrel{\vec{E}}{\mathrm{E}}\end{array}$ & 疍 & త్ & -1 & a & $m$ & 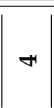 & in & 苞 & 畐 & $\mid$ & - & N & n & + & in & 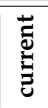 & 营 & है & $r$ & N & $n$ & H & in \\
\hline $\mathbf{P}$ & \multicolumn{25}{|c|}{ Energy Production } \\
\hline EP1 & Geothermal energy & 1 & 2 & 1 & & & & & & 3 & 3 & $\mid 0$ & & & & & & 1 & 2 & 1 & & & & & \\
\hline EP2 & Biomass & 1 & 2 & 1 & & & & & & 3 & 3 & 0 & & & & & & 2 & 2 & 0 & & & & & \\
\hline EP3 & Biogass & 1 & 2 & 1 & & & & & & 1 & 3 & 2 & & & & & & 2 & 2 & 0 & & & & & \\
\hline EP4 & $\begin{array}{l}\text { District heating } \\
\text { and cooling }\end{array}$ & 1 & 2 & 1 & & & & & & 2 & 3 & 1 & & & & & & 2 & 2 & 0 & & & & & \\
\hline EP5 & Heatpumps & 2 & 2 & 0 & & & & & & 3 & 3 & 0 & & & & & & 2 & 2 & 0 & & & & & \\
\hline EP6 & $\begin{array}{l}\text { Solar power } \\
\text { systems for } \\
\text { electricity } \\
\text { generation }\end{array}$ & 1 & 2 & 1 & & & & & & 2 & 3 & 1 & & & & & & 2 & 2 & 0 & & & & & \\
\hline EP7 & $\begin{array}{l}\text { Solar thermal } \\
\text { systems for cooling } \\
\text { generation }\end{array}$ & 1 & 2 & 1 & & & & & & 1 & 3 & 2 & & & & & & 2 & 2 & 0 & & & & & \\
\hline EP8 & $\begin{array}{l}\text { Solar thermal } \\
\text { systems for } \\
\text { domestic hot water } \\
\text { and/or heating } \\
\text { generation) }\end{array}$ & 2 & 2 & 0 & & & & & & 3 & 3 & 0 & & & & & & 3 & 2 & 0 & & & & & \\
\hline EP9 & Mini wind power & 1 & 2 & 1 & & & & & & 1 & 3 & 2 & & & & & & 1 & 2 & 1 & & & & & \\
\hline EP10 & $\begin{array}{l}\text { Combined Heat } \\
\text { and Power (CHP) }\end{array}$ & 1 & 2 & 1 & & & & & & 2 & 3 & 1 & & & & & & 2 & 2 & 0 & & & & & \\
\hline $\mathbf{R}$ & \multicolumn{25}{|c|}{ Energy Reduction } \\
\hline ER1 & Insulation & 31 & 3 & 0 & & & & & & 4 & 5 & $|1|$ & & & & & & 3 & 3 & 0 & & & & & \\
\hline ER2 & $\begin{array}{l}\text { Air tightness } \\
\text { building }\end{array}$ & 3 & 3 & 0 & & & & & & 4 & 5 & 1 & & & & & & 1 & 3 & 2 & & & & & \\
\hline ER3 & Micro climates & 1 & 1 & 0 & & & & & & 3 & 4 & $\mid 1$ & & & & & & 2 & 1 & 0 & & & & & \\
\hline ER4 & Envelope systems & 3 & 3 & 0 & & & & & & 4 & 5 & 1 & & & & & & 2 & 2 & 0 & & & & & \\
\hline ER5 & Hot water systems & 2 & 2 & 0 & & & & & & 3 & 3 & 10 & & & & & & 2 & 2 & 0 & & & & & \\
\hline ER6 & $\begin{array}{l}\text { Window and/or } \\
\text { glazing systems }\end{array}$ & 3 & 3 & 0 & & & & & & 4 & 5 & 1 & & & & & & 2 & 3 & 1 & & & & & \\
\hline ER7 & $\begin{array}{l}\text { Heating and } \\
\text { cooling emission } \\
\text { systems }\end{array}$ & 2 & 2 & 0 & & & & & & 2 & 3 & 1 & & & & & & 2 & 2 & 0 & & & & & \\
\hline ER8 & $\begin{array}{l}\text { Electric heating } \\
\text { systems }\end{array}$ & 2 & 2 & 0 & & & & & & 2 & 3 & 1 & & & & & & 3 & 2 & 0 & & & & & \\
\hline ER9 & $\begin{array}{l}\text { Artificial lighting } \\
\text { systems }\end{array}$ & 2 & 2 & 0 & & & & & & 3 & 3 & 0 & & & & & & 2 & 2 & 0 & & & & & \\
\hline ER10 & Ventilation systems & $2 \mid$ & 2 & 0 & & & & & & 4 & 4 & 0 & & & & & & 3 & 2 & 0 & & & & & \\
\hline $\mathrm{S}$ & \multicolumn{25}{|c|}{ Interdisciplinary Skills } \\
\hline IS1 & Communication & 3 & 3 & 0 & & & & & & 5 & 4 & 0 & & & & & & 3 & 3 & 0 & & & & & \\
\hline IS2 & $\begin{array}{l}\text { Information } \\
\text { management }\end{array}$ & 3 & 4 & 1 & & & & & & 4 & 5 & 1 & & & & & & 2 & 3 & 1 & & & & & \\
\hline IS3 & Collaboration & 3 & 3 & 0 & & & & & & 5 & 4 & 0 & & & & & & 2 & 3 & 1 & & & & & \\
\hline IS4 & Quality assurance & 31 & 4 & 1 & & & & & & 3 & 4 & $\mid 1$ & & & & & & 3 & 4 & 1 & & & & 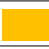 & \\
\hline IS5 & $\begin{array}{c}\text { Sustainable } \\
\text { architectural design }\end{array}$ & 2 & 3 & 1 & & & & & & 4 & 5 & 1 & & & & & & 2 & 2 & 0 & & & & & \\
\hline IS6 & Integrated design & 3 & 3 & 0 & & & & & & 4 & 5 & 1 & & & & & & 2 & 2 & 0 & & & & & \\
\hline IS7 & $\begin{array}{c}\text { Sustainable } \\
\text { building materials }\end{array}$ & 3 & 3 & 0 & & & & & & 4 & 5 & 1 & & & & & & 2 & 1 & 0 & & & & & \\
\hline IS8 & $\begin{array}{c}\text { Sustainable } \\
\text { installation } \\
\text { materials }\end{array}$ & 3 & 4 & 1 & & & & & & 4 & 4 & 0 & & & & & & 3 & 2 & 0 & & & & & \\
\hline IS9 & $\begin{array}{l}\text { Environmental } \\
\text { (indoor) quality }\end{array}$ & 3 & 3 & 0 & & & & & & 3 & 4 & 1 & & & & & & 3 & 2 & 0 & & & & & \\
\hline IS10 & Economics & 3 & 3 & 0 & & & & & & 4 & 4 & $\mid 0$ & & & & & & 2 & 2 & 0 & & & & & \\
\hline IS11 & Procurement & 2 & 3 & 1 & & & & & & 3 & 4 & $|1|$ & & & & & & 1 & 1 & 0 & & & & & \\
\hline
\end{tabular}


As previously presented under Section 2.3, based on these outcomes, seven national roadmaps were developed for seven EU pilot countries, together with a standard format for other interested countries. These roadmaps address the detected gaps and describe opportunities and barriers to training the required number of nZEB professionals. They can be found on the project website.

The current results are further elaborated in a common usable and task-based qualification framework on nZEB qualifications for professionals. Additionally, this framework is used to create a PROF/TRAC repository of CPD trainings on the project website and in the BUILD UP Skills advisor app. Thereby it becomes possible to narrowcast new trainings and training content on a task-based level for specific professionals.

\section{Discussion}

The skill mapping in PROF/TRAC was developed based on results with skill mapping in the Dutch BUILD UP Skills project BUS_N@W. In this project, the skill mapping consisted mainly of listing technologies and linking them to occupations, while the skills gap analysis was missing. In the new recently funded $\mathrm{H} 2020$ project BIMplement, the in PROF/TRAC developed methodology will be re-used and further developed.

During the development and piloting of the methodology for skills mapping, several issues for discussion evolved. The need for very clear definitions of all professions involved was detected for the inventory of professions. Even if it is a regulated profession, the same profession could have different roles and tasks, depending on the country. To that extent, it was important to make further distinctions within professions. For instance 'engineers' can have different competences, such as building engineer, mechanical engineer, etc. However, this is also a point where a certain flexibility should be allowed for EU member states. For example, the definition of a civil engineer in Croatia is totally different from a civil engineer in the Netherlands. This was also the case for building management, financing and procurement professionals etc. Hence the role and tasks of these kinds of professions are very country-specific and the level of skills need to vary accordingly.

This lead to the difficulty in defining the professions involved in nZEB on a European level, because of numerous national variations in titles and work areas, e.g., technical architect, energy engineer etc. As a result, the project consortium decided to work with groups of professions in various fields of work, such as architecture, construction and mechanical engineering. This way, it was easier to define the required level of nZEB skills on a European level for each group.

The inventory of current qualifications and numbers of professionals active in the field per country takes more time and depends on the accessibility of data on professional registrations, initial and post-initial training supply. None of the countries involved has a registration system for all professions involved in nZEB, except for architects.

Another lesson was learned during analysis of the skill mappings, which showed that especially the level of present skills is difficult to assess correctly, as it depends on the expertise and objectivity of the experts who undertake the mapping. Our recommendation is to train experts more intensively before conducting skill mapping, and to make use of better digital survey tools, instead of Excel. This will also enable skill mapping with larger expert groups, swift validation and, therefore, better reliability. Furthermore, after performing skill mapping, the results should be presented to and discussed with involved experts.

\section{Conclusions}

The developed methodology for execution of skill mapping and roadmap development worked well for all involved member states. With little effort, nZEB skill mapping can be performed by filling in the developed Excel document. During the PROF/TRAC train the trainers sessions, the executed skill mappings proved valuable in guiding and accelerating the design of new interdisciplinary trainings. Based on the first skill mappings carried out, it does not seem sensible to us to outline the parts of the 
mappings that are most problematic for each country. Because the number of involved experts was relatively small, further investigation of the detected skill gaps at country level is needed.

The results of seven national roadmaps concluded that none of the countries have a registration system for all professions involved in nZEB, except for architects. Therefore it is very difficult to estimate the exact number of professionals requiring training for nZEB. For better mobility of nZEB-trained professionals within Europe, we recommend setting up an easy to implement registration system including results from CPD in the future.

The seven national roadmaps illustrate how countries can deal with numerous national obstacles in reaching nZEB standards, such as cultural habits, tradition, legislation, tax system and financing. The seven existing roadmaps can be used in future as an example for other countries or similar initiatives. They are available for free on the project website.

As previously argued, a task-related scheme is important in the qualification scheme, which is independent of the professional assumed to perform the task. Some tasks may be performed by architects in one country, but by construction engineers in another country; for instance, construction calculations. This way it becomes possible to compare national implementations of the same qualification scheme more easily. The developed qualification framework, in combination with the skill gaps from the skill mapping can be used by CPD providers to optimize their CPD.

As a next step, a specific skill mapping with building managers from the social housing sector will be undertaken, using a cloud-based inventory system. It can be assumed that usage of cloud-based tools will speed up the skill mapping, lower the 'error rate', and quickly uncover possible misinterpretations of, for instance, the definitions used to describe professions, skill levels and technologies.

As a further research recommendation, it could be noted that the methodology should be statistically validated. In the PROF/TRAC project the methodology was developed and tested. By working with small focus groups of highly qualified professionals, the results provided a good indication of existing skill gaps that require attention in CPD. In many EU countries, formal education qualifications on nZEB are currently developed by similar small groups of experts. For statistical validation, we recommend the use of digital survey technologies and simplified cluster analysis to compare the results of larger datasets.

Supplementary Materials: Further information is available online at www.proftrac.eu.

Acknowledgments: This project has received funding from the European Union's Horizon 2020 research and innovation programme under grant agreement No. 649473. The sole responsibility for the content of this article lies with the authors. It does not necessarily reflect the opinion of the European Communities. The Executive Agency of Small and Medium Enterprises is not responsible for any use that may be made of the information it contains.

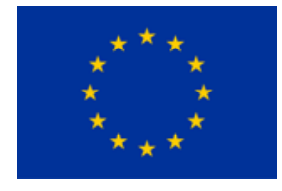

Author Contributions: Jan Cromwijk and the ISSO team were responsible for the skills mapping methodology and developed the national roadmaps; Project partner IVE and in particular Carolina Mateo-Cecilia and Cristina Jareño-Escudero tested the methodology during the project and applied it to Spanish case, wrote part of the abstract, introduction and contributed to general overview. The Architects' Council of Europe represents the stakeholder group of architects in the PROF/TRAC project and is the dissemination leader, Veronika Schröpfer wrote parts of the abstract, introduction and conclusion and edited the whole paper. Peter Op't Veld is the project coordinator and some parts of this paper originate from the proposal.

Conflicts of Interest: The authors declare no conflict of interest.

\section{References}

1. WBCSD. Energy Efficiency in Buildings 2.0. Action on Energy in Buildings; World Business Council for Sustainable Development: Geneva, Switzerland, 2012. 
2. Eurostat. Energy, Transport and Environment Indicators; Publications Office of the European Union: Luxembourg, 2016.

3. Brunsgaard, C.; Dvořáková, P.; Wyckmans, A.; Stutterecker, W.; Laskari, M.; Almeida, M.; Kabele, K.; Magyar, Z.; Bartkiewicz, P.; Veld, P.O. Integrated energy design-Education and training in cross-disciplinary teams implementing energy performance of buildings directive (EPBD). Build. Environ. 2014, 72, 1-14. [CrossRef]

4. Pacific Northwest National Laboratory and PECI. Advanced Energy Retrofit Guide: Office Buildings; U.S. Department of Energy: Washington, DC, USA, 2011.

5. Schröpfer, V.L.M.; Tah, J.; Kurul, E. Mapping the knowledge flow ins ustainable construction project teams using social network analysis. Eng. Constr. Archit. Manag. 2017, 24, 229-259. [CrossRef]

6. European Commission. Communication from the Commission to the European Parliament, the Council, the European Economic and Social Committee and the Committee of the Regions: An EU Strategy on Heating and Cooling; European Commission: Brussels, Belgium, 2016; Available online: https://ec.europa.eu/ transparency/regdoc/rep/1/2016/EN/1-2016-51-EN-F1-1.PDF (accessed on 22 May 2017).

7. WBCSD. Transforming the Market: Energy Efficiency in Buildings; World Business Council for Sustainable Development: Geneva, Switzerland, 2009.

8. Rodrigues, L.; Garratt, T.; Ebbs, N. Is added Sustainability equal added Value? Energy Convers. Manag. 2012, 63, 203-207. [CrossRef]

9. Thomson, C.; El-Haram, M.; Emmanuel, R. Mapping knowledge flow during sustainability assessment. Proc. Inst. Civ. Eng. Urban Des. Plan. 2010, 163, 67-78. [CrossRef]

10. Rohrbacher, H. Managing the technological transition to sustainable construction of buildings: A socio-technical perspective. Technol. Anal. Strateg. Manag. 2011, 13, 137-150. [CrossRef]

11. UNEP. Greening the Building Supply Chain; UNEP Sustainable Buildings and Climate Initiative: Paris, France, 2014.

12. Harris, D.; Gelegenis, J. Energy engineering: An emerging discipline. Eng. Educ. Curric. Pedag. Didact. Asp. 2014, 1, 145-163.

13. IDES-EDU Master and Post Graduate Education and Training in Multidisciplinary Teams. Final Publishable Report. August 2013. Available online: http://proftrac.eu/fileadmin/user_upload/IDES-EDU_Final_ Report.pdf (accessed on 14 September 2017).

14. Yang, X.; Ergan, S.; Knox, K. Requirements of Integrated Design Teams While Evaluating Advanced Energy Retrofit Design Options in Immersive Virtual Environments. Buildings 2015, 5, 1302-1320. [CrossRef]

15. Knudstrup, M. Barriers and challenges in the integrated design process approach. In Sustainable Built Environment and Construction; Proceedings of the International Conference on Asia-European Sustainable Urban Development, Chongqing, China, 4-6 June 2006; Yao, R., Li, B., Steemers, K., Eds.; Centre for Sino-European Sustainable Building design and Construction: Aalborg, Denmark, 2006; pp. 14-19.

16. Becchio, C.; Corgnati, S.P.; Delmastro, C.; Fabi, V.; Lombardi, P. The role of nearly-Zero Energy Buildings in the transition towards Post-Carbon Cities. Sustain. Cities Soc. 2016, 27, 324-337. [CrossRef]

(C) 2017 by the authors. Licensee MDPI, Basel, Switzerland. This article is an open access article distributed under the terms and conditions of the Creative Commons Attribution (CC BY) license (http:/ / creativecommons.org/licenses/by/4.0/). 